\title{
Dry Season Prevalence of Bovine African Trypanosomosis in parts of Bokkos Local Government Area of Plateau State, Nigeria.
}

\author{
C.O. Idehen", O.O. Obaloto ${ }^{* * *}$, R.O. Opabunmi ${ }^{* * *}$, O.O. Olaleye ${ }^{*}$, G.A. bongaby ${ }^{* * *}$, \\ L.A. Aluma", F. Gbadamosi" and C.T. Ikyase ${ }^{* * *}$ \\ "Nigerian Institute for Trypanosomiasis Research, Oyo State, ${ }^{* *}$ Nigerian Institute for \\ Trypanosomiasis Research, Vom, Jos South, Plateau State and ${ }^{* * *}$ Federal College of \\ Animal Health and Production Technology Vom, Jos South, Plateau State, Nigeria.
}

\begin{abstract}
THIS STUDY was carried out in 3 districts of Bokkos Local Government Area of Plateau State, Nigeria to determine the current dry season prevalence of African trypanosomosis in cattle. Blood Samples collected aseptically from 721 cattle were examined for trypanosome species using Buffy Coat and Giemsa staining methods. Out of 721 cattle randomly selected, 37 were found positive for trypanosome infection. This represents $5.1 \%$ over all trypanosome prevalence. Young Cattle ( $>3 y r s)$ had significantly higher prevalence $(p<0.05)$ rate of $7.2 \%$ than $3.2 \%$ trypanosome infection rate in adult cattle. Sex prevalence revealed male cattle had more prevalence of trypanosome infection rates (6.4\%) than the female counterparts $4.2 \%$. Although it was not statistically significant $(\mathrm{p}>0.05)$. Among all trypanosome species found in all the 3 districts investigated, Trypanosoma vivax was more dominant $(81.1 \%)$. However, there is a significant correlation $(\mathrm{r}=0.209)$ between prevalences of infection in all the districts investigated. Cattle with poor body condition showed more trypanosome prevalence of $7.1 \%$ than the good body conditioned ones $(4.2 \%)$ but there is no significant difference $(p>0.05)$ in their prevalence rates. The result of this study validates the presence of trypanosome infection in this study area. Hence, the need for continual surveillance, monitoring and evaluation of the status of animal trypanosomosis in Bokkos LGA of Plateau State, Nigeria.
\end{abstract}

\section{Introduction}

African trypanosomosis is one of the neglected tropical diseases ravaging rural populace ofthe sub-Saharan Africa. It is a disease that affect both man and animals (1). It has a serious economic effect and public health implications on the people (2).

African trypanosomosis has been targeted for elimination by 2020 during the meeting organized by World Health Organisation in 2012 (3). However, effort made by concerned agencies, NGO's, AU-PATTEC over the years at elimination of the disease seem not to have yielded positive result. Sustainability of this infection could be as a result of animal serving as a reservoir host. Hence, re-emergence of trypanosome infection cannot be ruled out.
Worrisome to public health professionals is a reported case of human infective trypanosome (T.brucei gambiense) now found in cattle (4). Population at risk (Veterinarian, hunters, cattle rearers and families, farmers, fishermen) who are always in contact with these animals and its vectors are likely to be infected with the disease.

Hence, Cattle a major livestock kept by herd owners in Nigeria (5) with the population of 1.07million reared in Plateau state, Nigeria (6) could be a source of trypanosome infection to man.

Ilemobade (7) also estimated 48million of these cattle inhabiting sub-Saharan African are at risk of contracting the disease annually. Therefore, African trypanosomosis still remain critically considered for livestock due to its 
zoonotic implication (8). Thisnecessitated the need to investigate the current prevalence of trypanosomosis in cattle in Bokkos Local Government Area of Plateau state, Nigeria.

\section{Materials and Methods}

\section{Study area}

The Study was conducted from March to May 2016 in 3 districts of Bokkos Local Government of Plateau State, Nigeria. It is the late dry season survey and these districts were selected randomly. Bokkos LGA is located between $9^{\circ} 00^{\prime} 10^{\prime \prime} \mathrm{E}$ and $9^{0} 18^{\prime} 00$ 'N.

The annual rainfall is $1400-1500 \mathrm{~m}$ and attitude over $1200 \mathrm{~m}$ above sea level. The major occupation of the inhabitants include crop production and livestock farming.

\section{Study population and sampling strategy}

A total of 721 cattle of both sexes and ages ( $<3$ yrs and $>3 y$ rs) were randomly selected for the study. The sample size was determined using Thrusfield (9) description with expected prevalence put at $13.08 \%$ (10). The body condition score was done according to Nicholson and Butterworth, (11) pattern but categorized into two broad groups: good body condition: $\mathrm{F}$ and $\mathrm{M}$ (non - prominent paralumbar fossa and ribcage), poor body condition: L- and M- (Prominent paralumbar fossa and Rib cage) where F - Fat, MMedium, L- Lean.

\section{Sample collection}

Three mililiters $(3 \mathrm{ml})$ of blood was aseptically collected from the jugular vein of each animal. The blood samples were put into an Ethylene
Diamine Tetra acetic Acid (EDTA) bottles, labelled and transported to the laboratory in an ice-packed boxes for analysis.

Parasitological study

The aseptically collected samples were examined by two diagnostic techniques, buffycoat (12) and Giemsa stained thin blood smear (13). Stained slides were examined under x100 microscopic magnification with oil immersion. Based on the features such as size and position of the kinetoplast, presence, or absence of flagellum, presence or absence of undulating membrane, and type of motility display under wet mount, the trypanosomes were identified.

\section{Statistical analysis}

Data obtained from the study were analysed using descriptive statistics. Percentages (\%) were calculated to determine prevalence of infection while chi-square $\left(\mathrm{x}^{2}\right)$ test was used to determine association between the prevalence of infection and epidemiological variables. Correlation coefficient was used to determine relationship between prevalence of infection among the districts.

Inferential statistics was carried out using SPSS Version 17.0. $\mathrm{P}$ value was set at $\mathrm{P}<0.05$.

\section{$\underline{\text { Result }}$}

Out of 721 Cattle examined, 37 were infected with trypanosomes with a total prevalencerate of $5.1 \%$. Sabon Barki recorded the highest prevalence of $6.1 \%$ while Daffo district had the lowest prevalence of infection $3.9 \%$ ( Table 1).

TABLE 1. Trypanosomiasis Prevalence in 3 Districts of Bokkos LGA.

\begin{tabular}{|c|c|c|c|c|c|}
\hline Districts & Co-ordinates & $\begin{array}{l}\text { Samples } \\
\text { collected }\end{array}$ & Samples negative & $\begin{array}{c}\text { Samples } \\
\text { positive }\end{array}$ & $\begin{array}{c}\text { Prevalence } \\
(\%)\end{array}$ \\
\hline Bokkos & $\begin{array}{c}09.31528 \mathrm{~N} \\
008.022212 \mathrm{E}\end{array}$ & 229 & 217 & 12 & $5.2 \%$ \\
\hline Daffo & $\begin{array}{c}09.20923 \mathrm{~N} \\
008.9836366 \mathrm{E}\end{array}$ & 231 & 222 & 9 & $3.9 \%$ \\
\hline SabonBarki & $\begin{array}{l}09.46475 \mathrm{~N} \\
009.02212 \mathrm{E}\end{array}$ & 261 & 245 & 16 & $6.1 \%$ \\
\hline Total & & 721 & 684 & 37 & $5.1 \%$ \\
\hline
\end{tabular}

Egypt. J. Vet. Sci. Vol. 50, No.1 (2019) 
Trypanosoma vivax was the most predominant trypanosome encountered (81.1\%) 30/37 in all the districts investigated. This was followed by T.brucei (16.2\%) 6/37 and T.congolense (2.7\%) 1/37 (Table 2). Spread of T.vivax in the 3 districts investigated shows Sabon barki had the highest rate of $46.7 \%$ (14/30) T.vivax while Bokkos and Daffo districts had $30.0 \%(9 / 30)$ and $23.3 \%(7 / 30)$ T. vivax respectively.
Trypanosoma congolense infection in cattle was not encountered in Daffo and Bokkos districts (Table 2).

Out of 324 young cattle ( $>$ 3yrs) examined, 25 $(7.2 \%)$ were infected with trypanosomes while only $12(3.2 \%)$ were infected out of 360 adult cattle (<3yrs) investigated. (Table 3 ).

TABLE 2. Trypanosome Distribution in the Districts surveyed

\begin{tabular}{|c|c|c|c|c|}
\hline \multirow[t]{2}{*}{ Districts } & \multicolumn{4}{|c|}{ Trypanosome Species } \\
\hline & T. vivax & T.congolense & T.brucei & $\begin{array}{c}\text { Total Positive } \\
\text { Sample }\end{array}$ \\
\hline Bokkos & $9(30.0 \%)$ & 0 & 3 & 12 \\
\hline Daffo & $7(23.3 \%)$ & 0 & 2 & 9 \\
\hline Sabon Barki & $14(46.7 \%)$ & 1 & 1 & 16 \\
\hline Total & $30(81.1 \%)$ & $1(2.7 \%)$ & $6(16.2 \%)$ & 37 \\
\hline
\end{tabular}

$\mathrm{X}^{2}=3.212 \quad \mathrm{df}=4 \quad \mathrm{p}$ value $=0.523$

$r=0.209$ (where $r$ is correlation coefficient of relationship)

TABLE 3. Prevalence of Infection in respect of Age

\begin{tabular}{cccccc}
\hline \multirow{2}{*}{ Category } & Variables & $\begin{array}{c}\text { Total Number of } \\
\text { Samples examined }\end{array}$ & $\begin{array}{c}\text { Number of } \\
\text { Samples } \\
\text { Negative }\end{array}$ & $\begin{array}{c}\text { Number } \\
\text { of Samples } \\
\text { positive }\end{array}$ & $\begin{array}{c}\text { Prevalence of Infection } \\
\text { (\%) }\end{array}$ \\
\hline \multirow{2}{*}{ Age } & Young $>3$ yrs & 349 & 324 & 25 & $7.2 \%$ \\
\cline { 2 - 6 } & Adult $<3$ yrs & 372 & 360 & 12 & $3.2 \%$ \\
\hline Total & 721 & 684 & 37 & $5.1 \%$ \\
\hline
\end{tabular}

Chi square $=5.734 \mathrm{df}=1 \mathrm{P}$ value $=0.017$

Sex prevalence showed male cattle were more infected with trypanosome species $(6.4 \%)$ than their female counterparts having a prevalence rate of $4.2 \%$ (Table 4 ).

Table 5 revealed poor body conditioned cattle had trypanosome infection rate of $7.1 \%$ higher than the infection rate $(4.2 \%)$ in Good body conditioned ones.

\section{Discussion}

This study was conducted in an area once declared free of trypanosomosis and its vectors (14).
The overall trypanosomosis prevalence of $5.1 \%$ found in cattle is relatively higher than previously reported prevalence by Idehen et al. (15) as $4.8 \%$ in Jos as well as $3.9 \%$ reported by Ameen et al. (16) at Ogbomoso in Nigeria. However, the observed prevalence of $5.1 \%$ in cattle is lower than $13.8 \%$ reported by Quadeer et al. (10) in Bassa LGA in the same Jos, Nigeria. The observed variation in the prevalent rate of bovine trypanosomosis reported in this work may be due to the season (late dry season) when this survey was carried out. Secondly, the husbandry practices adopted by the herds owners in the treatment of their sick animals and 
TABLE 4. Prevalence of Infection in respect to sex

\begin{tabular}{|c|c|c|c|c|c|}
\hline Category & Variables & $\begin{array}{c}\text { Total } \\
\text { Number } \\
\text { of Samples } \\
\text { examined }\end{array}$ & $\begin{array}{c}\text { Number of Samples } \\
\text { Negative }\end{array}$ & $\begin{array}{c}\text { Number } \\
\text { of } \\
\text { Samples } \\
\text { positive }\end{array}$ & Prevalence of Infection (\%) \\
\hline \multirow{2}{*}{ Sex } & Male & 314 & 294 & 20 & $6.4 \%$ \\
\hline & Female & 407 & 390 & 17 & $4.2 \%$ \\
\hline Total & & 721 & 684 & 37 & $5.1 \%$ \\
\hline
\end{tabular}

TABLE 5. Body condition score (BCS) and Trypanosome infection

\begin{tabular}{ccccc}
\hline Category & $\begin{array}{c}\text { Total number of } \\
\text { samples examined }\end{array}$ & $\begin{array}{c}\text { Number of Samples } \\
\text { Negative }\end{array}$ & $\begin{array}{c}\text { Number of } \\
\text { Samples positive }\end{array}$ & $\begin{array}{c}\text { Prevalence of } \\
\text { Infection (\%) }\end{array}$ \\
\hline Good BCS (F\&M) & 495 & 474 & 21 & $4.2 \%$ \\
\hline Poor BCS $\left(\mathrm{M}^{-}, \mathrm{L}^{-}\right)$ & 226 & 210 & 16 & $7.1 \%$ \\
\hline Total & & 684 & 37 & $5.1 \%$ \\
\hline
\end{tabular}

$\mathrm{X}^{2}=2.566, \mathrm{df}=1, \mathrm{p}$ value $=0.109$

vector control. Furthermore, the result shows no significant difference $(\mathrm{p}>0.05)$ in the prevalence of trypanosome infection among the 3 districts investigated with the spread of trypanosome species showing $r=0.209$ correlation among the districts.

This study has also shown that Trypanosoma vivax was the dominant species seen with aproportion of $81.1 \%$ prevalent rate. The finding is consistent with Fasanmi et al. (17) assertion that T. vivax has the highest prevalent rate of $66.67 \%$ and Idehen et al. (15) with T. vivax having $86.4 \%$ prevalent rate in their survey carried out.

The abundance of $T$. vivax species in this survey is attributed to its dual transmission possibilities, by vectors - mechanical and cyclical, as well as its short life cycle in the vector for 5 days (18). The lower prevalence of T.congolense $(2.7 \%)$ observed may be due to the fact that most of the Savannah species of tsetse flies (G.morsitans) which are major transmitters of $T$. congolense $(19,20)$ might have been eliminated by severe heat before the survey was carried out thereby preventing close vector-host contact. Age related prevalence as shown in table 3 revealed that young cattle below 3 years were more infected than cattle above 3 years old. This finding corroborates
Idehen et al. (15) assertion that younger animals are more prone to trypanosome infection than their adult counterparts. This observation that younger animals were more infected by trypanosome species than the adult ones is statistically significant $(\mathrm{p}<0.05)$. The probable reasons for younger animals being infected more than adult ones may be due to grazing of animals close to riverine areas during the dry season (the period when the survey was carried out) for good pasture and water. At this period most of the vectors have been driven to the cool habitat along the riverine areas making close host-vector contact achievable. Furthermore, the younger animals have very less dense coat which makes the penetration of the tsetse flies proboscis faster and easier. In this study, the prevalence of $6.4 \%$ recorded in male cattle was higher than the prevalence of $4.2 \%$ recorded in the female counterpart even though the difference of prevalence of infection in both sexes is not significant $(p>0.05)$. This finding is in line with previous reports by Idehen et al. (15), Sam-Wobo et al. (21) that male animals are more infected with trypanosome species than their female counterparts but differs from the findings of Kalu et al. (22) attributing more infection of trypanosome species to female animals than their male counterparts.

Egypt. J. Vet. Sci. Vol. 50, No.1 (2019) 
Behavioural pattern of male animals to lead the herds for pasture search prone them to be bitten first by infected tsetse fly before others. This is the probable reason why male animals are more infected than female counterparts.

Poor body conditioned cattle was observed to be more infected by trypanosome species (7.1\%) that the good body conditioned ones (4.2\%), even though there is no significant difference $p>0.05$ in their trypanosome prevalence. This may be due to the continual depletion of the body metabolism over a period of time by trypanosome species coupled with poor nutrition.

These findings are in agreement with the observation of Tafese et al. (2) that good body condition animals with good nutrition have less trypanosome infection rates than the poor conditioned ones.

\section{Conclusion}

Cattle are the source of income to the Fulani pastoralists and are their main occupation. It is also a source of protein and raw material for the leather industry. Prevalence of Trypanosomosis (5.1\%) recorded in cattle during a dry season period of the year should be worrisome. It shows a threat to sustainable livestock production as well as income generation. Hence, integrated control system involving elimination of vectors, treatment of infected animals and human as well as continual insecticide spray of tsetse flies habitat to prevent vector breeding should be carried out.

\section{References}

1. Soudre, A., Quedrago-kone, S., Wurzinger, M., Muller, S., Hanotle, O., Quedraogo, A.G. and Solkner, T.J. Trypanosomiasis: a priority disease in tsetse - challenged area of Burkina Faso. Tropical Animal health and Production, 45 (2), $497-503(2013)$.

2. Tafese, W., Melaku, A. and Fentahum, T. Prevalence of bovine trypanosomiasis and its 159 Vectors in two districts of East Wollega Zone, Ethopia. Onderstepoort Journal of Veterinary Research, 79 (1), E 1-4(2012).

3. WHO. Report of a WHO meeting on elimination of African Trypanosomiasis (Trypanosoma brucei gambiense) in Genvena. Programme against African Trypanosomosis, 36 (1), 2-3(2012).

4. WHO: Trypanosomiasis: Human African sleeping sickness. Fact SheetsNo.259/en/WHO, 2014, retrieved 25 -04-2014.
5. Samdi, S.M., Abenga, J.N., Attahir, A., Wayo, B.M., Sumayin HM, Haruna MK, Jijitar AM, Ogunwole RT, Ramatu RA, Bizi RL. Constraints in the Control of African Trypanosomiasis, the prevailing factors in Kurmin Kaduna, Northern Nigeria (Review article). International Journal of Animal andVeterinary Advance, 2 (1), 31-36 (2010).

6. Nkechi, V.O., Makama, S., Ishiaku, E., Micah, S.M., Jurbe, G.G., Dawurung, C., Olusola, O.O., Lohlum A. and Shamaki, D. Ethno-botanical survey of medicinal plants used in thetreatment of animal diarrhoea in plateau state, Nigeria. $B M C$ Veterinary Research, 7, 36 (2011).

7. Ilemobade, A. Tsetse and Trypanosomiasis in Africa: The challenges, theOpportunities. Onderste Poort Journal of Vet. Research, 76 (1), $35-40$ (2009).

8. Schofield, C.I., kabayo, J.P. Trypanosomiasis, Vector control in Africa and Latin America. Parasite Vector, 1 (1), 24 (2008).

9. Thrusfield, M.V. Veterinary Epidemiology's third Edition, Blackwell publishing, Oxford, Great Britian, 1-584 (2005).

10. Quadeer, M.A., Danbirni, S, Usman, M., Akogun, O.B., Gundiri MA, BobboAG.Prevalence of bovine trypanosomiasis in Bassa Local government area, Plateau State. Nigeria Journal of Parasitology, 29 (2), 136-139(2008).

11. Nicholson, M.J. and Bulterworth, M.H., A guide to condition scoring of Zebu Cattle, ILCAAddis Ababa/ 1986/ 235.

12. Woo, P.T., Evaluation of the haematocrit and other technique for the diagnosis of African trypanosomiasis. Acta Tropica, 27 (4), 384-386 (1970).

13. Wilson, A.J., Value of the indirect fluorescent and antibody test as a serological and Diagnosis of Glossina transmitted bovine trypanosomiasis. Tropical Animal health Production, 1 (2), 89-95 (1969).

14. Majekodunmi, A.O., Akinyemi, F., Charles, D., Picozzi, K., Thrusfield, M.V. and Welburn, S.C., A longitudinal Survey of African animal Trypanosomiasis in domestic cattle on the Jos Plateau, Nigeria. Prevalence, distribution and risk factors. Parasite Vectors, 6, 239 (2013).

Egypt. J. Vet. Sci. Vol. 50, No.1 (2019) 
15. Idehen, C.O., Ishola, O.O., Adeyemi, I.G., Abongaby G, Olaleye, O.O., Aluma, A.L., Opabunmi, R.O. and Obaloto, O.B. Prevalence of African Trypanosomosis in cattle and sheep in Bassa Local Government area of Plateau state, Nigeria. Sokoto Journal of Veterinary Science, 16 (3) 11-17 (2018).

16. Ameen, B.A., Joshua, R.A., Adedeji, O.S., Raheem, A.K., Akingbade, A.A. and Leigh, O. Preliminary Studies on prevalence of Ruminant Trypanosomiasisin Ogbomoso area of Oyo state, Nigeria. Middle East Journal of Scientific Research, 3 (4), 214 (2008).

17. Fasanmi, O.G., Okoroafor, U.P., Nwufoh, O.C., Bukola Obale, U.M. and Ajibola, E.S. Survey ofTrypanosomiasis Species $n$ cattle from three farms in Iddo Local Government Area, Oyo State. Sokoto Journal of Veterinary Science, 12 (1) 57-61 (2014).

18. Dadah, A.J., Ikeh, E.I., Ayanbimpe, G., Omotainse, O.S., Dede, P.M. and Igwe, A.C., Animal Trypanosomosis in Kaura Local Government Area, Kaduna State, Nigeria.Microbiology Research Journal International, 21 (6), 1-6 (2017).

19. Mulligan, H.W. The African Trypanosomiasis. GeorgeAllen and Unwin,London, Pp. 769-770 (1970).

20. Dagnachew, S. and Shibeshi, S., Prevalence and Vector distributions of bovine Trypanosomiasis in control (Sibu sire) and non-control (Guto Gida) districts bordering upper Anger Valley of East Wollega zone, Western Ethiopia. Ethiopian Veterinary Journals, 15 (2), 77-86 (2011).
21. Sam-Wobo, S.O., Igenezoa, A.J., Idowu, O.A. and Otesile, E.B., Ekpo UF, Kehinde OO. Bovine Trypanosomiasis and its Impact on cattle in derived Savannah areas of Ogun State, Nigeria. Journal of Public Health and Epidemiology, 2 (3), 42-47 (2010)

22. Kalu, A.U., Uzoukwu, M. and Ikeme, M.M. Prevalence of Tsetse fly and Ruminant Trypanosomosis in Katsina-Ala Local Government Area, Benue State, Nigeria. Romanian Archives of Microbiology and Immunology, 55 (4), 34135223.(1996).

23. Map data (2016) Google Map of Plateau State showing all the local Government Areas. http:// www.nigerianmuse.com/20100527092749zg/ sections/pictures-maps-cartoons/maps-of-variousstates-and-their-local-government-in-nigeria/. Retrieved 22-2-2016.

(Received 19/02/2019; accepted 19/05/2019) 